\title{
Speaking and Writing Interconnections: A Systematic Review
}

\section{Fouad Akki', * '[0000-0002-7421-4584]', Mohammed Larouz ${ }^{1}$}

${ }^{1}$ Department of English Studies, School of Arts and Humanities, Moulay Ismail University, Morocco

$\begin{array}{lllllll}\text { Received: 07.06.2021 } & \text { • } & \text { Accepted: 07.08.2021 } & \text { • } & \text { Published: 12.08.2021 } & \text { • Final Version: 12.08.2021 }\end{array}$

\begin{abstract}
Drawing on previous studies on the relationship between speaking and writing modalities, this paper provides a critical synthesis of theoretical and empirical research on the interconnections between the two versions. Along with this, this systematic review shows that research on the issue at hand has been classified under three main categories: a) speaking effect on writing; b) writing effect on speaking, and c) correlation between speaking and writing. While experimental research has emphasized the impact of speaking and writing on each other, correlational endeavors have been much concerned with the symmetrical, reciprocal, and predictive connections between these two interrelated domains. Overall, the current review suggests that learning a second or foreign language could be enhanced by complementing speaking tasks by writing ones and vice versa. In this case, speaking could be taught along with writing to allow students to transfer their skillfulness from one to the other.
\end{abstract}

Keywords: Connection, correlational research, experimental research, speaking, writing

\section{Introduction}

Speaking and writing, as productive skills, are thought to play a central role in language development (e.g., Izumi, 2002; Mackey, 2002; Swain, 1985, 1995). It is, for example, thought that "output," or language production, pushes learners to process language more deeply and with more mental effort than when interpreting language through reading and/or listening alone, and complete grammatical processing may not be possible without the production of "output" (Swain, 1995). Hence, speaking and writing play a great role in the process of language development.

Taken unconnectedly, speaking skills are thought to be very important for so many reasons. Ur (2000) claims that mastering speaking skills gives the impression of being competent in all the other language skills; he stated that "of all the four skills, speaking seems intuitively to be the most important; people who know a language are referred to as 'speakers' of the language, as if speaking included all other kinds of knowing" (p. 12). In the process of language learning, interactive speaking is thought to play a great role in interlanguage development to generate better input, force syntactic processing, take risks, develop automaticity, and develop discourse skills (Skehan, 1998, pp. 16-19). In oral learning, encountering clues like intonation and gesture enhances understanding (Dawes, 2008, p. 44). Accordingly, oral skills should be taught before writing skills because time for oral rehearsal of the sentence is of key importance as well (Hiatt \& Rooke, 2002, p. 31).

Equally important, writing has also been regarded as a major component in language learning classrooms. Being proficient in writing indicates successful learning of a second language (Hyland,

*Corresponding Author: fouad.akki@gmail.com 
2003; Nickerson et al., 2014). Because most exams often rely on the students' writing proficiency to measure their knowledge, strong writing skills may improve their chances for success (Alexander, 2008). Furthermore, Kellogg (2001) states that writing is a cognitive process that tests memory and thinking ability. Writing involves a lot of thinking and dialogue with oneself to recall data and commit it to paper. Therefore, it is thought to help students reinforce the grammatical structures, enhance vocabulary, and assist other skills such as reading, listening, and speaking (Kellogg, 2008).

Despite the aforementioned importance of the two productive modalities, most of previous research has tended to delve into the positive impact that these separate language skills may have on the overall learning process and thus ignore the interconnections between them (Hubert, 2008; Larouz, 2012; Benattabou, 2021). Before that, Weissberg (2006) already stated that many foreign language instructors have not considered the differences in their students' proficiency in speaking and writing. According to these scholars, the relationship between speaking and writing has not received much attention from EFL/ESL teachers and researchers and it has not yet earned a place in the English language teaching literature. According to Hubert (2013), studies have not directly investigated the relationship between the development of speaking and writing proficiencies among foreign language learners despite the constraints that students face in both versions (Akki \& Larouz, 2020; Gatcho \& Ramos, 2020).

Afterwards, these alarms have led researchers to examine the connections between speaking and writing. Understanding such relationship between speaking and writing may give more insights into this domain and determine whether these skills inform and serve each other. To that end, the present paper is meant to review the previous theoretical and empirical studies on the issue at hand.

\section{Theoretical Studies}

Stotsky (1987) states that there are two current theories on the relationship between speaking and writing. The first one is the "unidirectional model" or "recoding model" and the second is the "multidirectional model" or "interactive model" (Moran, 1987).

"Unidirectional model" regards this relationship as one-way sequence in which speech determines the development of writing. Hence, speech influences writing which is thought to be derived from speech. Writing is a representation of speech, and it is "simply a way of preserving speech and can be referred to metaphorically as 'frozen speech"' (Moxley, 1990, p. 127). In other words, the theory holds that writing depends on speech. "Unidirectional model", therefore, focuses on correspondences and similarities between speech and writing because writing is thought to represent spoken language.

With regards to the correspondences from speech to writing, transcribing speech sounds into writing or what is referred to as 'encoding' is a classic classroom practice that corresponds to this model. In other words, students are asked to convert speech sounds into individual letters and letter combinations. Concerning the correspondences from writing to speech, students are to be taught "how to read aloud through 'decoding' with a phonics emphasis" (Moxley, 1990, p. 128). Differently said, students convert individual written letters and letter combinations into speech sounds: "Once a visual word code makes contact with the phonological word code in reading, we assume that the meaning of the word can be elicited by means of a direct associative connection between the phonological unit and the semantic meaning unit" (LaBerge \& Samuels, 1985, p. 703). In this model, therefore, encoding and decoding were thought to be sufficient for students to acquire literacy.

However, Moxley (1990) stated that the theory's conceptions were put under scrutiny, and it was criticized for many reasons. First, language is reduced to individual sounds and discrete words to be transcribed or decoded, which is not enough to comprehend language as a 
discourse that goes beyond the word and sentence level. Second, this model is more inclined to the early behavioristic thought that emphasizes the stimulus and response theory. In this case, correspondences between speech (stimulus) and writing (response) constitute the core of this model which was criticized for the same reasons that led to the inadequacy of behavioristic approaches. Third, this theory implies that spoken language must be learned before written language, and this is contradicted by the fact that many deaf-mutes (people who are deaf and unable to speak) can acquire the ability to write a foreign language without being able to speak or understand the spoken language.

In addition to the deficiencies mentioned by Moxley, contextual aspects of words were not given attention in this model and enhancing language comprehending cannot be attained without context. Finally, believing that writing is a representation of speech assumed more similarities and correspondences between the two and neglected the fact that speech and writing are different from each other in so many aspects.

As an alternative to the first model, "Multidirectional model" considers the one-way influence of speech on writing but adds that writing can also influence speaking as a reversal to the unidirectional effect of speech on writing. Moreover, writing development is thought to be influenced by multidirectional influences (e.g., reading). The unidirectional model is more concerned with similarities and correspondences between speech and writing, whereas the multidirectional theory emphasizes the differences between speaking and writing.

Stosky (1987) explained the difference between the first theory/ unidirectional model and the second theory/multidirectional model. In the first theory, oral language influences structures' meaning in both reading and writing at all levels of literacy development. In this case, reading and writing cannot independently influence each other since both are influenced by spoken language. Furthermore, spoken and written language are not assumed to be different from each other, but rather similar. The assumptions of the first model can be represented in Figure 1 below:

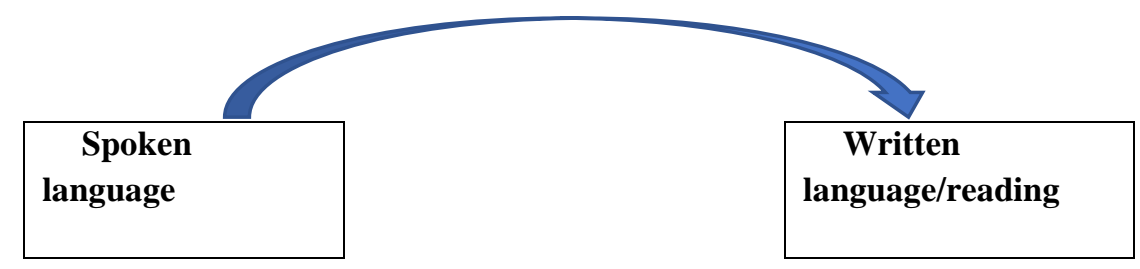

Figure 1. Unidirectional model (adapted from Stotsky, 1987)

On the other hand, the second theory accounts for the impact of spoken language on written language but it emphasizes the impact of written language on spoken language as well as the impact of reading and writing on each other. In other words, developing literacy entails multidirectional effects; reading and written language influence each other, and spoken and written language, in turn, affect each other. The basic assumption of this theory, in contrast to the first one, is that oral and written language are different from each other. The assumptions of the second theory can be represented in Figure 2 below:

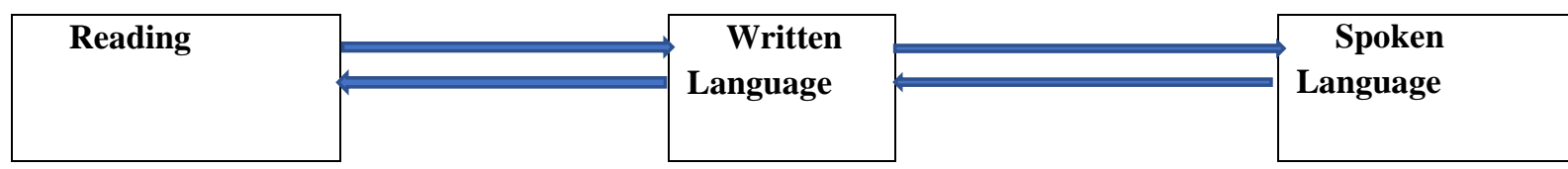


Figure 2. Multidirectional model (adapted from Stotsky, 1987)

In line with the assumptions of the second theory above, writing research has indicated many differences between speaking and writing, various impacts on literacy and writing development, and more influences of writing on speech than the unidirectional proposes (e.g., Clanchy, 1979; Ehri \& Wilce, 1986; Havelock, 1986; Householder, 1971; Olson, Torrance, \& Hildyard, 1985; Ong, 1982; Stubbs, 1980). Hence, the multidirectional theory operates in several directions; it accounts for the unidirectional impact of speech on writing, the directional impact of writing on speech, the impact of reading and writing on each other, and the similarities as well the differences between speaking and writing. Therefore, instruction that relies solely on matching speech and writing is not likely to develop literacy.

Matching speech and writing is also supported, but not as an exclusive factor for literacy to occur. To develop literacy, mainly the ability to write, proponents of the multidirectional model advocated what is called a 'print environment' to expose students to reading a variety of texts and reading of their writing products (Moxley, 1990). Stotsky (1987) also found that the evidence for literacy skills being enhanced by other variables in literacy is stronger than the evidence that supports writing being improved by speech activities alone. Writing activities can improve comprehension, and "reading experience seems to be a consistent correlate of, or influence on, writing ability" (Stotsky, 1983, p. 637).

Along the same vein, Sulzby (1986) stated that "current research in young children's writing and reading development suggests that it is erroneous to think that children in literate societies acquire writing and reading as 'written language' after they have acquired 'oral language'" ( $\mathrm{p}$. 50). Consequently, the development of literacy does not necessarily depend on the development of speech. In particular, the growing studies on emergent literacy contradict the notion that literacy development simply waits upon the development of speech (Moxley, 1990).

It is apparent then that this model, unlike the unidirectional theory, shifts the attention from emphasizing letters and sounds as discrete elements to highlighting written texts (reading) that are more suitable to understand language as great stretches of discourse rather than isolated letters, sounds, or words. In this case, exposing students to a variety of texts provides access to the ways in which writing differs from speech.

In brief, the multidirectional theory is assumed to be more acceptable on the grounds that it accounts for the impact of speaking and writing on each other as well as the impact of reading and writing on each other, the non-exclusive impact of speech on writing, and similarities as well as differences between speaking and writing. In addition to the impact of speech on writing, writing can be enhanced by relying on writing activities and reading a variety of texts that enable the learners to distinguish speaking from writing. Hence, "there appears to be stronger and more consistent evidence in support of the second theory" (Stotsky, 1987, p. 385).

\section{Empirical Studies in L1 and L2}

L1 research dealing with the connection between speaking and writing is viewed as a starting point to investigate the relationship between the two modalities in L2. Research carried out about childhood literacy is pertinent in this context.

For example, Weissberg (2006) stated that the last thirty years have witnessed many endeavors to examine the role of speaking in the development of literacy; speaking thus has been viewed as the 'first writing' that is produced by children in their L1. He stated that the earliest writing of children reflects their spoken language. In other words, this type of writing is similar in terms of form and content to children's oral language. According to him, many rhetorical strategies developed by early writers are derived from "social conversation". 
Abilities like choosing and developing a topic, providing information about that topic, and shaping the message for a particular audience are conversational aspects that can be transferred to the expository and persuasive writing (Weissberg, 2006, p. 10).

Similarly, Kroll (1981) investigated the developmental relationships between speaking and writing in three grades (three, four and six grades) with the aim of comparing between speaking and writing when students explained a board game in tow modalities. It was revealed that spoken forms were better than written ones in grades three and four, but in grade six the spoken and written versions were almost the same and students were equally proficient. This implies that writing abilities develop by age and younger learners' speaking and writing are more differentiated if compared with the older learners. Therefore, there is a developmental trend in the connection between speaking and writing in L1.

Furthermore, Cayer and Sacks (1979) investigated the writing of eight L1 English students studying at college and found that it showed various aspects of speech, which indicates that their oral abilities affected their written performance. Hence, it was suggested that there is a transfer of skills from speaking to writing because the two modalities were not distinctive even at the university level.

These L1 findings, however, might not be applied to L2 settings in which the learners do not possess the ability to speak at an early age and in which spoken and written aspects of language are introduced simultaneously.

In an ESL setting, Weissberg (2006) observed the relationship between levels of proficiency in speaking and writing and identifies three different routes that ESL learners with various levels of aptitude take to develop English language literacy. The first group are learners who have extensive previous exposure to spoken target language; they are likely to be more outgoing, open, extrovert and sociable people but may have lower writing abilities. For these learners, there is tiny and a little lexical and syntactic difference between their writing and speech; writing includes many of the same conversational aspects that characterize spoken language. However, their writing develops and becomes less speech-like and resembles academic writing with continued instruction. The second group consists of learners who may be competent in writing in their L1 but have little exposure to the foreign language. This group may be shy and unable to communicate using the foreign language. Weissberg (2006) gives the example of 32 years old graduate student: a professor and researcher from Mexico who travelled to USA to pursue his $\mathrm{PhD}$ in engineering. This learner could write extensively in his L1 and managed even to produce some scholarly publications. Subsequently, he received formal training and read substantial technical material in L2. In his English classes, this learner had the ability to write well. However, his spoken ability was far below his writing ability; his spoken language was broken and hesitant. Hence, achieving native-like proficiency in speaking was beyond his reach. The learner's writing develops, but his speaking does not. The third group are learners whose proficiency in speaking and writing develop and advance at similar rates. Weissberg (2006) terms this route as a "case of symmetrical development" (p. 39).

Overall, if speaking pushes writing forward along with it to develop in the first route and writing develops without speaking improvement in the second route, in the third route speaking and writing develop at similar rates and go forward hand in hand. Weissberg's three routes to literacy are displayed in Table 1 below:

Table 1. Weissberg's three routes to L2 literacy

\begin{tabular}{|c|c|c|c|c|}
\hline Initial Speaking & Initial Writing & Final Speaking & & Final Writing \\
\hline High & Low & $\Longrightarrow$ & + & Medium/High \\
\hline
\end{tabular}




\begin{tabular}{|c|c|c|c|c|c|c|c|}
\hline 2 & Low & + & High & $\Longrightarrow$ & Low & + & High \\
\hline 3 & Low & + & Low & $\Longrightarrow$ & Medium/High & + & Medium/High \\
\hline
\end{tabular}

In light of these three routes, Weissberg (2006) called for change in the way ESL writing is taught. He suggested that spoken and written language be presented in a balanced way in L2 writing classrooms; this could allow learners proficiency in one skill support the development of the other skill. Weissberg $(1994,2006)$ also emphasized the importance of dialogue in enhancing writing practices in ESL classrooms.

Despite the importance of Weissberg's observations, it is also prerequisite to support these initial endeavors with additional empirical evidence. Hence, for the sake of clarity and simplification, the other following ESL and EFL previous empirical studies will be classified under three main categories: the studies that investigate the impact of speaking on writing, the studies that investigate the impact of writing on speaking, and the studies that deal with the correlation between the two skills.

\subsection{Speaking Effect on Writing}

Speaking practices are said to support writing proficiency in EFL and ESL classrooms. Florez and Hadaway (1987) state that oral language development can influence writing behavior, but the oral language proficiency scores may not indicate what to expect from learners in written composition.

In a case study that investigated the teaching practices of three ESL teachers, Cumming (1992) believed that the speaking activities enhance the development of writing and asserted that creating and directing whole class discussion was proved very useful in both promoting interpersonal communication among class participants and providing those students with clearer and more relevant ideas that could help them in speaking and writing. Discussions can be used to enhance the interpersonal communication between learners and to generate ideas as well as rhetorical features that can guide and support writing processes. Because writing is thought to be one of the most difficult language skills for EFL learners, speaking activities, in this case, can prepare learners to write more effectively.

Similarly, Manglesdorf (1989) and Weissberg (1994) have also asserted that classroom dialogue, as already mentioned, replicates the mental tasks involved in composing and thus raises learner awareness of the cognitive processes involved in writing, including generating ideas, selecting and organizing propositional content, encoding propositions into text, and evaluating whether the resulting text actually communicates what the writer is intending (Weissberg, 1994).

In the same vein, Yun et al. (2012) examined the impact of taking a public speaking course on learners' writing abilities in an American university. It was assumed that public speaking would enhance students' writing abilities. To justify this assumption, the researchers recruited 678 participants in their investigation; they were divided into two groups. The first group of participants were enrolled in a public speaking course, while the second group were not. Participants produced a three- to five- page paper at the beginning of the semester and a second one twelve weeks later. The researchers compared the papers relying on the American Association of College and Universities written communication VALUE rubric that is composed of five dimensions: Structure, control of syntax, context, content development, and sources and evidence. Comparing the two groups reveals that public speaking influences 
positively the learners' writing abilities in structure use and control of syntax. Other dimensions were not affected.

Equally important, Rausch (2015) examined the impact of speaking instruction on writing abilities of English learners in U.S.A and its implications for instruction. Specifically, the study was aimed to testify whether speaking instruction practices that are meant to develop argumentative speaking also develop argumentative writing skills. Pre- and Posttest argumentative essays were collected for analysis before and after speaking instruction as a treatment in this case study. Results reveal that teaching students how to argue in speaking has a positive impact on the students' ability to write argumentatively. Thus, speaking instruction is transferable and can serve writing abilities.

Finally, Al-Roomy (2016) conducted a case study to investigate the effect of oral interactions on the ability to deal with composition exercises among Saudi Arabia university students while working in groups. The researcher assumed the possibility of improving writing skills through oral interactions in EFL contexts. To prove this, the researcher relied on open ended questions to elicit the attitudes of three different groups of 50 students classified based on their English proficiency levels and on transcripts of audiotaped recordings of interactions between students. The results suggested that integrating writing and oral interactions helped the students to view writing process more comprehensively. Furthermore, the findings highlighted the importance of group work in developing the interpersonal skills that are vital for learning listening, speaking, interpersonal organization, as well as providing constructive feedback, and so forth. These results also supported writing as a collaborative activity that allows students to benefit from their mistakes as well as from the mistakes of their classmates in an interactive way.

In brief, research dealing with speaking impact on writing reveal a positive influence of speaking activities that foster interaction and dialogue on writing abilities of ESL and EFL students (e.g., Cumming, 1992; Manglesdorf, 1989; Weissberg, 1994; Yun et al., 2012; Rausch, 2015; Al-Roomy, 2016). These studies that writing ability of EFL and ESL students can be enhanced by integrating discussions, dialogues, public speaking, and oral interaction in teaching practices. Because writing is thought to be cognitively demanding, ability in writing could be supported and learners can be prepared to write relying on speaking activities such as discussions and oral interactions. Despite the importance of such conclusions, it is still of great interest to examine the impact of writing on speaking which is also a compelling area for researchers to reflect on.

\subsection{Writing Effect on Speaking}

If speaking is thought in most studies to influence writing abilities of ESL and EFL students based on the previously mentioned findings, other researchers have delved into the impact of writing on speaking. For instance, Silva (1990) remarks that writing generally follows a standardized form of grammar, structure, and vocabulary which is inseparable from the structure of spoken sentences. Consequently, writing practice can maximize students' conscious awareness of the sentence structures while speaking and enhance their speaking proficiency.

In the same vein, it has been assumed that written input can have a beneficial effect on oral output. Lotter (2012) states that "integrating written language with oral production for young learners might lead to greater gains in oral proficiency" (p. 54). Because the affective filter is thought to be higher in speaking than in writing, learners can consider writing as a starting point to get more confidence and prepare themselves to speak effectively (Williams, 2008). Hence, previous studies claim that 
instead of learning to write students should write to learn (e.g., E-lkoumy,1998; Kim, 2008; Blake, 2009).

El-Koumy (1998) conducted a study to investigate the effect of journal writing on EFL students' speaking proficiency. The participants were 136 Egyptian university students. They were divided into two groups: experimental and control groups. Both groups received regular instruction. Journal writing was taught only to the participants of the experimental group. The two groups were pretested and post-tested on speaking skills. The results reveal no significant difference between the two groups on the pre-test of the oral skills. However, the experimental group obtained higher scores on the post-test of oral skills, which indicates that journal writing has a positive impact on students' speaking performance.

Subsequently, Rokni and Seifi (2014) attempted to examine the effect of journal writing on EFL learners' accuracy and fluency. Forty-eight (48) male intermediate level students, who were randomly selected from two classes at a language institute, participated in the study. They were divided into two groups: the experimental group and the control group. The experimental group was offered extra teaching of journal writing at the end of twenty term-long sessions. The results of the posttest showed a significant difference between the two groups in terms of accuracy and fluency in speaking proficiency. Hence, journal writing helps learners to communicate more effectively, fluently, and accurately. The study provided guidelines for teachers of English to help adult learners overcome the speaking barriers and develop their abilities of communication using the target language.

With a limited number of participants, Kim (2008) conducted a study on ESL two beginning students of five and six years of age. The two participants were taught using two different types of instruction: Integrated instruction (written and oral) and only oral-based instruction. The study is meant to compare between the effect of the two approaches on oral skills of these learners. The results reveal that integrated-based instruction yield better performance of learners' speaking skills in oral assessment measures. Hence, it is asserted that writing is likely to impact positively the development of oral skills among young EFL learners.

In the same vein, Nation and Newton (2009) believe that written input can be a very influential factor to encourage speaking. In a research on the effect of written input on negotiation, Newton (1995) found out that all the vocabulary used by learners for negotiation are the ones present in their written input. Hence, the development of verbal working memory of the oral proficiency can directly be influenced by the quality of the writing assignments (MacArthur et al., 2008).

Additionally, Blake (2009) conducted a similar exploratory study by investigating the effect of internet chats on adult learners' oral fluency in an ESL setting. Thirty-four (34) university students were divided into 3 groups: the first group were taught in text-based chat environment, the second were taught using traditional face-to-face interactions, and the third were taught without any interaction of any kind. After six weeks of instruction, the participants' speaking ability was tested and the results reveal that students who were taught in text-based chat instructional environments obtained higher scores in oral assessment and outperformed the other two groups. Hence, internet chats were thought to enhance students' speaking abilities and contribute to develop fluency and the automation of lexical and grammatical knowledge.

Conducting similar research, Sanchez (2014) investigated whether the written input and output (writing activities) affect oral language development of young learners of English. Written input on the board is supposed to be read by students and the written output consists of activities such as 'filling in the gaps' and 'circling the correct answer'. After eight weeks of teaching young sixteen (16) EFL learners in Spain relying on both oral and written input/output in the experimental group 
and on just oral input in the control group, an oral test was used to obtain data. The test consists of a question-and-answer task, picture description, and L1 translation tasks. The number of target words and accuracy of target lexical items, semantic pragmatic appropriateness of target structures, syntactic acceptability of target structures, and L1 translation were used as criteria to measure the effect on the learners' oral output. The experimental group outperformed the control group participants and they showed higher scores in all the variables tested. The results are in line with the previous studies conducted to examine the impact of writing on speaking abilities suggesting that learners should write to learn, and that speaking performance can benefit from integrating written input and output in EFL contexts.

Likewise, Fathali and Sotoudehnama (2015) investigated the impact of guided writing practice on the speaking proficiency of Iranian elementary EFL students. Two elementary classes were selected to participate in this study. The participants were assigned randomly into the experimental (n: 26) and the control group (n: 26). In each teaching session, the experimental group was provided with extra 10 guided writing worksheets in the last 15 to 20 minutes of each class, whereas the control group worked in their workbooks doing exercises in the mentioned time. The quantitative analysis of the posttest indicated a significant improvement of students' speaking proficiency in the experimental group compared to the control group. Moreover, semi-structured interviews administered to the subjects of experimental group revealed that they held positive attitudes towards the integration of guided writing practices in English classes.

Overall, almost all the above previous studies concluded that writing abilities affect speaking proficiency in a positive way (e.g., El-koumy,1998; Kim, 2008; Williams, 2008; Blake, 2009; Nation \& Newton, 2009; Rokni \& Seifi, 2014; Sanchez, 2014; Fathali \& Sotoudehnama, 2015). Journal writing, integrated based instruction of speaking and writing, written input and output, and guided writing practice are likely to have a positive impact on learners' speaking abilities. Hence, 'writing to learn' is proven by evidence from the previous studies to enhance spoken language.

Nevertheless, investigating the impact of these skills on each other cannot provide researchers in the field with reliable findings that account for the symmetrical or asymmetrical development of proficiency in speaking and writing. In other words, whether these modalities develop at similar or different rates is out of reach of experimental investigations. Such issues can be examined efficiently by correlational research.

\subsection{Correlational Studies}

It is still of great interest to include correlational research to enrich insights into this domain. The available research shows that ability in speaking is associated with ability in writing (Geva, 2006, p. 14). For instance, Hubert (2008) investigated the relationship between writing and speaking in the U.S university Spanish language classroom. The study sought to characterize and analyze the relationship between the development of writing and speaking proficiencies among 40 native English-speaking learners of Spanish as a foreign language at beginning, intermediate, and advanced levels. The participants were divided into five (5) groups based on their level of proficiency and with eight (8) subjects in each group. The whole group holistic proficiency correlation for the three levels showed a strong positive correlation between writing and speaking proficiencies $(r=.849)$. Moreover, the results of correlation between writing and speaking proficiencies of the five groups are as follows: group $1(\mathrm{r}=.444)$, group $2(\mathrm{r}=.582)$, group $3(\mathrm{r}=.803)$, group $4(\mathrm{r}=.726)$, and group $5(\mathrm{r}=.917)$. The results reveal a moderate positive correlation between speaking and writing at beginning levels and much stronger correlation at the intermediate and advanced levels. Hence, these 
results suggest that there is a developmental trend in the relationship between writing and speaking proficiencies in foreign language contexts. The same conclusion was deduced by Croll (1981) in investigating the relationship between the two modalities in L1 as mentioned before. Therefore, "the more advanced these subjects become, the more closely their writing proficiency matches their speaking proficiency" (Hubert, 2008, p. 98).

Subsequently, Hubert (2013) examined the relationship between the development pace of speaking and writing proficiencies among 17 EFL learners of Spanish enrolled in beginning, intermediate, and advanced levels at a U.S university. They were administered the ACTFL oral proficiency interview and a writing proficiency test. Hubert's study was meant to correlate between the scores that were obtained in speaking and writing. The study revealed a strong positive correlation $(r=.863)$ between speaking and writing proficiencies of the 17 learners of Spanish.

In the same direction, Zhu (2008) examined whether syntactic maturity can be used as a reliable measurement to investigate the relationship between English speaking and writing. In this endeavor, forty (40) randomly selected ESL university students studying in an American university participated in the study. The written samples were obtained relying on diagnostic essay writing for a collegelevel course in composition at one American university, while the spoken samples were gathered by the students' participation in a semi- direct, tape-mediated oral proficiency test (the Video Oral Communication Instrument (VOCI) that uses video stimuli to elicit answers from the participants. The responses were recorded using an audio recorder. Lexical complexity was used as a measure to examine the lexical development of speaking and writing of 10 ESL students taken out from the previously mentioned 40 participants. The study explored two main areas: the correlation between speaking and writing and the differences between the two modalities in terms of lexical complexity. Specifically, these measures are mean T-Unit length (MTUL), mean error-free T-Unit length (MEFTUL), and percentage of error-free T-unit (\%EFTU), subordination ratio (SR), mean clause length (MCL) and dependent clauses per clause (DC/C).)

The results reveal a strong positive correlation in terms of measures of syntactic maturity; MTUL showed the strongest correlation with a correlation coefficient $(r=.85)$ followed by DC/C $(r=.75)$, \%EFTU $(r=.72)$, SR $(r=.71)$, MCL $(r=.67)$ and MEFTUL $(r=.67)$. Therefore, these results support the assumption that a learner with good speaking abilities is a learner with good writing abilities too and vice versa. Concerning the differences between speaking and writing, the study showed that the written samples contained longer T-units, longer clauses and longer error-free $\mathrm{T}$ units and incorporated more dependent clauses than the spoken samples.

Similarly, Cheung and Chang (2009) conducted a study to examine the relationship between English writing and speaking skills among Hong Kong primary students. The researchers relied on large sample of primary students: 11000 of primary 3 students and 12000 of primary 6 students from 1133 schools. The students were assigned oral and written assessments. The speaking tasks include short oral presentations, teacher-student interactions on a given topic, two-minute picture description, and expression of personal experiences. The study revealed a moderate correlation between speaking and writing among primary $3(\mathrm{p} .3)$ and primary 6 (p.6) students $(r=.55$ and $r=.49$ respectively). However, because of the large sample size, those moderate correlations were statistically significant $(\alpha<.05)$ revealing that any correlation between the two modalities is not due to chance.

In the same vein, Cheung and Leung (2011) investigated the relationship between speaking and writing with of the aim of improving and enhancing the English language proficiency in Hong Kong. Their stratified sample included 180 secondary 3 (Grade 9) students that were chosen randomly from six schools in Hong Kong. Each student delivered a presentation and took a writing assessment with 
similar or matching topics in both modalities. The researchers' aims were to correlate between speaking and writing sub-constructs like 'ideas \&organization', and 'vocabulary\& language patterns' (this includes the length of T-units, grammar and vocabulary). The results of the study revealed a strong positive correlation that ranges respectively from $(r=.663)$ to $(r=.735)$ between these sub-constructs across speaking and writing. This suggests that these previous sub-constructs can be transferred from speaking to writing and vice versa. In other words, students who are good at vocabulary and language patterns in writing, for example, can transfer this ability to speaking and vice versa. Conversely, learners who have problems in vocabulary and language patterns in speaking are likely to have the same constraints in writing and vice versa.

Coming up with similar results, Cahyono and Mutiaraningrum (2016) conducted a study to examine the relationships between EFL students' proficiency in writing and ability in public speaking across personality learning styles. The researchers recruited 74 participants for their study. They were enrolled in an 'Essay Writing' course in one of the English departments in Indonesia. The undergraduate students were divided into three classes and were told that they had to complete two tasks: writing cause and effect essays about language teaching issues and delivering an oral presentation on the same topic. The written essays and oral presentations were assessed to get scores of both. So that the scores could be reliable, two scoring rubrics were used, and two raters participated in the scoring process to account for inter-rater reliability. Moreover, a questionnaire was used to classify the students based on their learning styles; being introvert or extrovert in the context of this investigation. The results of the research reveal that public speaking abilities are strongly related to the writing abilities for both groups of introverts $(r=.718)$ and extrovert $(r=.646)$ students. The study shows that there is no significant difference between the speaking and writing abilities of extrovert and introvert students.

In a recent study, Akki and Larouz (2021) examined the relationship between speaking and writing in descriptive discourse among Moroccan university EFL students. To attain this end, 80 undergraduate semester six students studying English as a foreign language were randomly selected to participate in the current study. Subsequently, speaking and writing proficiency tests were administered to the participants to measure their descriptive abilities in speaking and writing. The results reveal that there is a strong positive and statistically significant correlation between speaking and writing in descriptive discourse, $r=.61$. Descriptive speaking can predict 37 percent of EFL students' descriptive writing $(\mathrm{R} 2=.37)$.

To sum up, EFL and ESL research examining the relationship between speaking and writing modalities revealed that these skills are interrelated to each other; development of one of these modalities is associated with the development of the other (e.g., Hubert, 2008, 2011; Zhu, 2008; Cheung \& Chang ,2009; Cheung \& Leung ,2011; Cahyono \& Mutiaraningrum, 2016; Akki \& Larouz, 2021).

\section{Conclusion}

The previous investigations on the connection between speaking and writing reveal, on the one hand, that these modalities have a positive impact on each other. Correlational research, on the other hand, shows that speaking and writing are strongly related to each other; and as speaking scores go up writing ones go up too and vice versa. Accordingly, the current synthesis gives rise to draw some theoretical and practical implications.

First, it is worth mentioning that the theoretical backgrounds underlying the relationship between speaking and writing emphasized only the comparative and experimental sides of this relationship. 
In other words, the 'unidirectional model' emphasized the similarities between spoken and written language as well as the exclusive impact of speaking on writing. In contrast, the 'multidirectional model' highlighted the similarities and the differences between spoken and written language and the impact of speaking and writing on each other. Despite the importance of such models as theoretical bases in deciphering the kind of relationships between the two modalities, they give much importance to the similarities and differences between speaking and writing and the exclusive impact of speaking on writing and the mutual impact of both on each other. Hence, they seem to be more pertinent to comparative and experimental research rather than correlational research. A 'correlational model', in this case, can be added to the previous theoretical backgrounds to account for the symmetrical relationships between speaking and writing. Regardless of similar and distinctive aspects of both as well as the impact that they may exert on each other, this model can account for the symmetrical, reciprocal, and the predictive relationships between them.

With regards to classroom practices, the mutual impact of speaking and writing on each other might suggest the idea of complementing the tasks of each modality with the tasks of the other. For instance, speaking can be used a good start in writing activities. Writing, in this case, could be supported through engaging students in interactions and discussions and make use of speaking to brainstorm and activate the students' background knowledge about the topics assigned in writing. Conversely, speaking in EFL contexts could be enhanced by allowing learners to plan and organize in advance their speaking tasks by writing down their ideas, notes, and vocabulary before being engaged in speaking tasks. The reason why this is so important is that both speaking and writing are cognitively demanding due to their productive nature (Akki \& Larouz, 2020; Ait Hammou, Larouz $\&$ Fagroud, 2021); hence, teachers and learners can use one modality to support the other and speaking activities could be preceded by writing ones and vice versa. Besides, language proficiency can be sustained by using strength and ability in one modality to support the other.

Additionally, because previous correlational research shows that speaking and writing are strongly related to each other, teaching one of them could be done along with the other to allow students to transfer their skillfulness in one modality to the other. Thus, the learners' abilities in one modality are to be sustained by their abilities in the other by adhering to complementary tasks in which speaking and writing co-exist together and exchange mutual transfer of shared aspects.

While the findings of previous studies are compelling here, future researchers are encouraged to come up with further comparative, experimental, and correlational data on the relationship between speaking and writing. In this case, other hypotheses pertaining to speaking and writing connections might come into play. Future research, in turn, is required to back up our assumptions on the issue at hand with additional empirical evidence.

\section{References}

[1] Ait Hammou, B., Larouz, M., \& Fagroud, M. (2021). Word frequency, Range and Lexical diversity: Picking out Changes in Lexical Proficiency among University Learners in an EFL Context. International Journal of Linguistics and Translation Studies, 2(2), 22-38. https://doi.org/10.36892/ijlts.v2i2.131

[2] Akki, F., \& Larouz, M. (2020). Comparative studies of spoken and written language with implications for EFL classrooms. In M. Yeou, R. Erguig \& B. Benzehaf (Eds.), New Perspectives in the Study of Language, Culture and Translation: Proceedings of the Second Doctoral Symposium (Eljadida) (pp. 247-264). Rabat: Edition \& Impression Bouregreg. 
[3] Akki, F., \& Larouz, M. (2021). The Relationship between Speaking and Writing in Descriptive Discourse in a Moroccan University EFL Context. International Journal of Linguistics and Translation Studies, 2(1), 124-13 https://doi.org/10.36892/ijlts.v2i1.102

[4] Alexander, M. (2008). Good writing leads to good testing. Retrieved from http://www.stickyminds.com/sitewide.aspype=ART

[5] Al-Roomy, M. (2016). Developing students' EFL writing skills by enhancing their oral interactions. International Journal of Applied Linguistics \& English Literature, 5(5),24- 32. Retrieved from http://dx.doi.org/10.7575/aiac.ijalel.v.5n.5p.24

[6] Benattabou, D. (2021). Gendered Hegemony in the Visual Discourse of Moroccan EFL Textbooks: A Quantitative Content Analysis. International Journal of Linguistics and Translation Studies, 2(1), 40-61. https://doi.org/10.36892/ijlts.v2i1.103

[7] Blake, C. (2009). Potential of text-based internet chats for improving oral fluency in a second language. Modern Language Journal, 93, 227-240.

[8] Cahyono, B. Y., \& Mutiaraningrum, I. (2016). Indonesian EFL students' proficiency in writing and ability in speaking across personality learning styles. Studies in English Language Teaching, 4(2), 168-186. DOI $: 10.22158 /$ selt.v4n2p168

[9] Cayer, R. L., \& Sacks, R. K. (1979). Oral and written discourse of basic writers: Similarities and differences. Research in the Teaching of English, 13(2), 121-128.

[10] Cheung, K. M., \& Chang, R. (2009). The relationship between the sub-components of English writing and speaking skills among Hong Kong primary students. Paper presented at the International Conference on Primary Education.

[11] Cheung, K. M., \& Leung, F. F. Y. (2011). Using assessment data to investigate the relationships between speaking and writing. Assessment and Learning (1), 140-156.

[12] Clanchy, M. T. (1979). From memory to written record. Cambridge, MA: Harvard U. Press.

[13] Cumming, A. (1992). Instructional routines in ESL composition teaching: A case study of three teachers. Journal of Second Language Writing, 1, 17-35.

[14] Dawes, L. (2008). The Essential Speaking and Listening. Routledge.

[15] Ehri, L. C., \& Wilce, L. S. (1986). The influence of spelling on speech. In D. Yaden \& S.Templeton (Eds.), Metalinguistic awareness and beginning literacy (pp. 101-114). Exeter, NH: Heinemann.

[16] El-Koumy, A. S. A. (1998). Effect of dialogue journal writing on EFL students' speaking skill. Retrieved from ERIC database (ED424772).

[17] Fathali, S., \& Sotoudehnama, E. (2015). The impact of guided writing practice on the speaking proficiency and attitude of EFL elementary learners. The journal of teaching language skills, 7(1), 1-25. DOI: https://dx.doi.org/10.22099/jtls.2015.3456

[18] Florez, V., \& Hadaway, N.L. (1987). Relationship of oral language proficiency and writing behaviors of secondary second language learners. Paper presented at the Southwest Regional Conference of the International Reading Association. (15 ${ }^{\text {th }}$, Phoenix, AZ, January -24, 1987).

[19] Gatcho, A. R., \& Ramos, E. T. (2020). Common Writing Problems and Writing Attitudes among Freshman University Students in Online Learning Environments: An Exploratory Study. Journal of Translation and Language Studies,1(1), 49-66. https://doi.org/10.48185/jtls.v1i1.6

[20] Geva, E. (2006). Second-language oral proficiency and second-language literacy. In D. August, \& T. Shanahan (Eds.), Developing literacy in second-language learners: Report of the National Literacy Panel on Language-Minority Children and Youth. Mahwah, NJ: Lawrence Erlbaum Associates, Inc.

[21] Havelock, E. A. (1986). The muse learns to write. New Haven, CN: Yale U. Press.

[22] Hiatt, K., \& Rooke, J. (2002). Creativity and writing skills: Finding a balance in the primary classroom. New York: David Fulton Publishers.

[23] Householder, F. W. (1971). The primacy of writing. In his Linguistic speculations (pp. 244-264). London: U. Press Cambridge.

[24] Hubert, M. D. (2008). The relationship between writing and speaking in the U.S university Spanish language classroom. Unpublished Thesis. Purdue University Library.

[25] Hubert, M. D. (2013). The development of speaking and writing proficiencies in the Spanish language classroom: A case study. Foreign Language Annals, (46)(1), 88-95.DOI: https://doi.org/10.1111/flan.12010

[26] Hyland, K. (2003). Second language writing. Cambridge: Cambridge University Press. 
[27] Izumi, S. (2002). Output, input enhancement, and the noticing hypothesis: An experimental study of ESL relativization. Studies in Second Language Acquisition, 24, 541-577.

[28] Kellogg, R. T. (2001). Long-term working memory in text production. Memory \& cognition, 29(1), 43-52.

[29] Kellogg, R. T. (2008). Training writing skills: A cognitive developmental perspective. Journal of writing research, 1(1), 1-26.

[30] Kim, Y. (2008). The effects of integrated language-based instruction in elementary ESL learning. Modern Language Journal, 92, 432-451.

[31] Kroll, B. M. (1981). Developmental relationship between speaking and writing. In B. Kroll \& R. Vann, (Eds). Exploring Speaking-writing Relationships: Connections and Contrasts (pp.32-54). Illinois: National Council of Teachers of English.

[32] LaBerge, D., \& Samuels, S. J. (1985). Toward a theory of automatic information processing in reading. In H. Singer \& R. B. Ruddell (Eds.), Theoretical models and processes of reading (689-718). Newark, DE: International Reading Association.

[33] Larouz, M. (2012). Reading and writing ability in descriptive \& argumentative discourse: Moroccan university students as a case study. LAP Lambert Academic Publishing AG \& Co KG.

[34] Lotter, M. C. (2012). Multiple perspectives on the role of English literacy skills in the curriculum of young English as a foreign language (EFL) learner in a Taiwanese urban context. MSU Working Papers in Second Language Studies, 3, 53-64.

[35] MacArthur, A. C., Graham, S., \& Fitzgerald, J. (2008). Handbook of writing a research (6th ed.). New York: The Guildford Press.

[36] Mackey, A. (2002). Beyond production: Learners' perceptions about interactional processes. International Journal of Educational Research, 37, 379-394.

[37] Manglesdorf, K. (1989). Parallels between speaking and writing in second language acquisition. In D. Johnson \& D. Roen (Eds.), Richness in writing: Empowering ESL students (pp. 134-145). London : Longman.

[38] Moran, M. R. (1987). Epilogue. Topics in language disorders, 7, 86-89.

[39] Moxley, R. A. (1990). On the relationships between speech and writing with implications for behavioral approaches to teaching literacy. The Analysis of Verbal Behavior, 8, 127-140.

[40] Nation, I. S. P., \& Newton, J. (2009). Teaching ESL/EFL listening and speaking. New York, NY: Routledge.

[41] Newton, J. (1995). Task-based interaction and incidental vocabulary learning: A case study. Second Language Research, 11(2), 159-176.

[42] Nickerson, R. S., Perkins, D. N., \& Smith, E. E. (2014). The teaching of thinking. Routledge, United Kingdom.

[43] Olson, D. R., Torrance, N., \& Hildyard, A. (Eds.). (1985). Literacy, language, and learning. Cambridge: Cambridge U. Press.

[44] Ong, W. J. (1982). Orality and literacy. New York: Methuen.

[45] Rausch, P. (2015). The relationship between English speaking and writing proficiency and its implications for instruction. Culminating Projects in English, 34. Retrieved from https://repository.stcloudstate.edu/engl_etds/34

[46] Rokni, S. J. A., \& Seifi, A. (2014). Dialog journal writing and its effect on learners' speaking accuracy and fluency. Study in English language teaching, 2(1), 28-37.

[47] Sanchez, M. A. (2014). The effect of written input on young EFL learners' oral output. Journal of English studies, 12, 7-33. DOI:10.18172/jes.2821

[48] Silva, T. (1990). Second language composition instruction: Development, issues, and directions in ESL. In B. Kroll (Ed.), Second language writing: Research insights for the classroom (pp.11-23). New York, NY: Cambridge University Press.

[49] Skehan, P. (1998). A Cognitive approach to language learning. Oxford: Oxford University Press.

[50] Stotsky, S. (1983). Research on reading/ writing relationships: A synthesis and suggested directions. Language Arts, 60(5), 627-642.

[51] Stotsky, S. (1987). A comparison of the two theories about development in written language: Implications for pedagogy and research. In R. Horowitz \& S. J. Samuels (Eds.), Comprehending oral and written language (pp. 371-395). New York: Academic Press. 
[52] Stubbs, M. (1980). Language and literacy: The sociolinguistics of reading and writing. London: Routledge and Kegan Paul.

[53] Sulzby, E. (1986). Writing and reading: Signs of oral and written language organization in the young child. In W. H. Teale \& E. Sulzby (Eds.), Emergent literacy: Writing and reading (pp. 50-89). Norwood, NJ: Ablex.

[54] Swain, M. (1985). Communicative competence: Some roles of comprehensible input and comprehensible output in its development. In S. Gass \& C. Madden (Eds.), Input in second language acquisition (pp. 235256). Rowley, MA: Newbury House.

[55] Swain, M. (1995). Three functions of output in second language learning. In G. Cook \& B. Seidlehofer (Eds.), Principles and practice in the study of language (pp. 125-144). Oxford: Oxford University Press.

[56] UR, P. (2000). A course in language teaching: Practice and theory. Cambridge: Cambridge University Press.

[57] Weissberg, R. (1994). Speaking of writing: Some functions of talk in the ESL composition class. Journal of Second Language Writing, 3, 121-139.

[58] Weissberg, R. (2006). Connecting speaking and writing in second language writing instruction. Ann Arbor: University of Michigan Press.

[59] Williams, J. (2008). The Speaking-writing connection in second language and academic literacy development. In D. Belcher \& A. Hirvela (Eds.), the Oral/Literate Connection: Perspectives on L2 Speaking, Writing, and Other Media Interactions. Ann Arbor: University of Michigan Press.

[60] Yun, K. A, Costantini, C., \& Billingsley, S. (2012). The effect of taking a public speaking class on one's writing abilities. Communication Research Reports, 29(4), 285-291. DOI:10.1080/08824096.2012.723270

[61] Zhu, X. (2008). Is syntactic maturity a reliable measurement to investigate the relationship between English speaking and writing? The Asian EFL Journal, 10(1), 133-153.

\section{About the authors:}

FOUAD AKKI holds a PhD in Applied Linguistics from Moulay Ismail University. His research interests include the four language skills, curriculum development, discourse analysis, ecolinguistics, bilingualism and multilingualism. He is a high school teacher and a part-time teacher at the department of English, the school of Arts and Humanities Meknes, Morocco.

MOHAMMED LAROUZ holds a PhD in Applied linguistics from Fez University. His research interests include issues related to Applied Linguistics and language teaching in Morocco, TEFL, sociolinguistics, research methodology, and communication. He is the Head of the English department and a full Professor of Applied Linguistics at the school of Arts and Humanities, Meknes, Morocco. 